\title{
Enhanced killing of chordoma cells by antibody-dependent cell- mediated cytotoxicity employing the novel anti-PD-L1 antibody avelumab
}

\author{
Rika Fujii ${ }^{1}$, Eitan R. Friedman ${ }^{1}$, Jacob Richards ${ }^{1}$, Kwong Y. Tsang ${ }^{1}$, Christopher R. \\ Heery $^{1}$, Jeffrey Schlom ${ }^{1}$ and James W. Hodge ${ }^{1}$ \\ ${ }^{1}$ Laboratory of Tumor Immunology and Biology, Center for Cancer Research, National Cancer Institute, National Institutes \\ of Health, Bethesda, MD, USA \\ Correspondence to: James W. Hodge, email: jh24ld@nih.gov \\ Keywords: chordoma, programmed death-ligand 1 (PD-L1), antibody-dependent cell-mediated cytotoxicity (ADCC), cancer \\ stem cells, immunotherapy \\ Received: March 21, 2016 \\ Accepted: April 26, 2016 \\ Published: May 09, 2016
}

\section{ABSTRACT}

Chordoma, a rare bone tumor derived from the notochord, has been shown to be resistant to conventional therapies. Checkpoint inhibition has shown great promise in immune-mediated therapy of diverse cancers. The anti-PD-L1 mAb avelumab is unique among checkpoint inhibitors in that it is a fully human IgG1 capable of mediating antibody-dependent cell-mediated cytotoxicity (ADCC) of PD-L1-expressing tumor cells. Here, we investigated avelumab as a potential therapy for chordoma. We examined 4 chordoma cell lines, first for expression of PD-L1, and in vitro for ADCC killing using NK cells and avelumab. PD-L1 expression was markedly upregulated by IFN-Y in all 4 chordoma cell lines, which significantly increased sensitivity to ADCC. Brachyury is a transcription factor that is uniformly expressed in chordoma. Clinical trials are ongoing in which chordoma patients are treated with brachyury-specific vaccines. Co-incubating chordoma cells with brachyury-specific $\mathrm{CDB}^{+} \mathrm{T}$ cells resulted in significant upregulation of PD-L1 on the tumor cells, mediated by the CD8 ${ }^{+} \mathbf{T}$ cells' IFN-Y production, and increased sensitivity of chordoma cells to avelumab-mediated ADCC. Residential cancer stem cell subpopulations of chordoma cells were also killed by avelumab-mediated ADCC to the same degree as non-cancer stem cell populations. These findings suggest that as a monotherapy for chordoma, avelumab may enable endogenous NK cells, while in combination with T-cell immunotherapy, such as a vaccine, avelumab may enhance NK-cell killing of chordoma cells via ADCC.

\section{INTRODUCTION}

Chordoma is a rare bone cancer thought to arise from remnants of the embryonic notochord. Approximately 300 new cases per year are diagnosed in the United States, accounting for $20 \%$ of primary spine tumors and $1 \%-4 \%$ of all malignant bone tumors $[1,2]$. Reported 5- and 10-year survival rates are about $70 \%$ and $40 \%$, respectively, a reflection of the slow-growing nature of the disease. Surgery followed by radiotherapy is the standard of care for primary tumors. However, based on anatomic location and tumor size on presentation, a wide curative excision is rarely feasible [2]. Hence, incidence of disease recurrence is common and metastases have been reported in up to $40 \%$ of cases. Once metastases develop, median survival is about 1 year [1]. No treatment for advanced chordoma has been approved by the U.S. Food and Drug Administration (FDA), since chordoma is largely resistant to conventional chemotherapy [3]. Thus, there is an urgent need for novel therapeutic modalities for this disease.

Immunotherapy has become an important treatment option for chemotherapy-resistant cancers. Brachyury, a transcription factor uniformly expressed in chordoma [4], 
appears to be an oncogenic driver for this tumor type [5, 6]. In addition to being a diagnostic marker for chordoma, brachyury may be a potential target for treatment $[7,8]$. Clinical trials of brachyury-specific vaccines are ongoing in chordoma patients. In addition, drugs that inhibit the immune checkpoints programmed cell death protein 1 (PD-1) and its major ligand, programmed death-ligand 1 (PD-L1), have shown clinical activity in diverse cancer types [9-11]. The FDA first approved a PD-1 inhibitor for melanoma; more recently, a PD-1 inhibitor was approved for lung cancer. Numerous clinical trials of several drugs targeting the PD-1/PD-L1 axis are ongoing in a range of cancers. Most of these PD-L1 antibodies are the IgG4 isotype and the Fc-modified IgG1 isotype, both of which inhibit the interaction of PD-1 on immune cells with PDL1 on tumor cells [12]. Avelumab, a fully human IgG1 anti-PD-L1 monoclonal antibody (mAb), is the only antiPD-L1 mAb that both induces antibody-dependent cellmediated cytotoxicity (ADCC) and blocks the PD-1/PDL1 pathway. Previously, our group reported that avelumab enhanced ADCC on several cancer cell lines expressing PD-L1 [13]. Other studies have shown that PD-L1 is expressed in chordoma cell lines and chordoma tissue samples [14, 15].

Here, for the first time, we demonstrate the potential of anti-PD-L1 antibody therapy for chordoma and report that (a) PD-L1 expression induced by IFN- $\gamma$ increased the sensitivity of chordoma cells to lysis by natural killer (NK) cells via avelumab-mediated ADCC; (b) tumor antigenspecific $\mathrm{CD}^{+} \mathrm{T}$ cells indirectly induced PD-L1 expression on chordoma cells; (c) upregulated PD-L1 expression on chordoma cells indirectly induced by brachyury-specific $\mathrm{CD}^{+} \mathrm{T}$ cells increased the sensitivity of chordoma cells to avelumab-mediatedADCC; and (d) residential cancer stem cell (CSC) populations in chordoma cells were killed by avelumab-mediated ADCC to the same degree as nonCSC populations within the cells. Our findings suggest that while chordoma responds poorly to conventional therapies such as surgery, radiotherapy, and chemotherapy, immune-mediated therapy may have clinical benefit for some chordoma patients.

\section{RESULTS}

\section{Treating chordoma cells with IFN- $\gamma$ upregulates MHC-I and PD-L1 expression}

It has been previously shown that IFN- $\gamma$ upregulates MHC-I expression in cancer tissue [16, 17]. It has also been reported that IFN- $\gamma$ upregulates PD-L1 expression in select chordoma cell lines [14, 15]. However, the potential of anti-PD-L1 antibody therapy in chordoma has not previously been shown. We first examined whether IFN- $\gamma$ could modulate expression of MHC-I and PD-L1 in chordoma cell lines established from 4 chordoma patients [18-21]. All 4 cell lines expressed HLA-ABC and PD-L1, and both molecules were upregulated by IFN- $\gamma$ in all 4 cell lines (Figure 1A). HLA-ABC expression in JHC7 cells treated with IFN- $\gamma$ increased 1.4-fold relative to untreated controls $(P<0.001$; Figure 1B). Similarly, IFN- $\gamma$ treatment upregulated HLA-ABC expression $(P<0.001)$ in UMChor1 (1.35-fold), U-CH2 (2.52-fold), and MUG-Chor1 cells (1.56-fold). Moreover, IFN- $\gamma$ significantly increased PD-L1 expression $(P<0.001)$ in JHC7 (3.03-fold), UMChor1 (8.06-fold), U-CH2 (1.99-fold), and MUG-Chor1 cells (1.99-fold; Figure 1C).

\section{Expression profiles of IFN- $\gamma$-induced genes in UM-Chor 1 cells}

To further examine the molecular consequences of treating chordoma cells with IFN- $\gamma$, we assessed IFN- $\gamma$-induced gene expression profiles of UM-Chor1 cells by microarray analysis (Supplemental Figure 1A). IFN- $\gamma$ treatment upregulated genes in UM-Chor1 cells $>1.5$-fold relative to untreated controls $(P<0.05)$. The highest upregulation was seen in gene TP53INP2 (tumor protein p53 inducible nuclear protein 2 ), which regulates transcription and enhances starvation-induced autophagy [22]. The second highest upregulation was seen in gene $C E B P D$ (CCAAT/enhancer binding protein [C/EBP] $\delta)$, which regulates proinflammatory gene expression $[23,24]$. IFN- $\gamma$ treatment downregulated some genes in UM-Chor1 cells $>1.5$-fold relative to untreated controls ( $P<0.05$; (Supplemental Figure 1B). The most downregulated gene, CLDN2, has been identified as a tight junction-specific integral membrane protein [25] whose expression is affected by cytokines [26]. The second most downregulated gene, PHACTR $4 I$, is a tumor suppressor gene that is mutated or downregulated in several cancers [27]. Supplemental Figure 1C shows the predicted pathway of IFN- $\gamma$-induced PD-L1 expression, as deduced from the results of microarray analysis. The transcription factor $C E B P D$ is induced by IFN- $\gamma$, leading to inhibition of $M Y C$ and activation of TLR9, IL10, and $T N F$, and culminating in upregulation of PD-L1 (CD274) expression. Taken together, these results suggest that $C E B P D$ is potentially involved in the pathway of IFN- $\gamma-$ induced PD-L1 expression in chordoma cells.

\section{IFN- $\gamma$-treated chordoma cells showed increased sensitivity to NK-cell lysis via avelumab-mediated ADCC}

Previously, our group reported that avelumab, an anti-PD-L1 antibody, enhanced NK cell-mediated lysis via ADCC on several cancer cell lines that express PD-L1 [13]. We next performed an in vitro assay for avelumabmediated ADCC to assess the functional significance 
of PD-L1 in chordoma cell lines (Figure 2). Avelumab increased NK-cell lysis 3.1-fold $(P=0.01)$ in JHC7 cells relative to isotype control. Similarly, avelumab increased
NK-cell lysis relative to isotype control in UM-Chor1 (3fold; $P=0.016)$, U-CH2 (1.7-fold; $P=0.029)$ and MUGChor 1 cells $(1.7$-fold; $P=0.006)$. When the cells were

A.

\begin{tabular}{|c|c|c|c|c|c|c|c|c|c|c|}
\hline \multirow[t]{4}{*}{ Cell line } & \multirow[t]{4}{*}{ Derivation } & \multirow[t]{4}{*}{ HLA } & \multicolumn{4}{|c|}{ HLA-ABC expression } & \multicolumn{4}{|c|}{ PD-L1 expression } \\
\hline & & & \multicolumn{4}{|c|}{$\mathrm{IFN}-\gamma$} & \multicolumn{4}{|c|}{$\mathrm{IFN}-\gamma$} \\
\hline & & & \multicolumn{2}{|l|}{-} & \multicolumn{2}{|l|}{+} & \multicolumn{2}{|l|}{-} & \multicolumn{2}{|l|}{+} \\
\hline & & & $\%$ Positive & MFI & $\%$ Positive & MFI & $\%$ Positive & MFI & $\%$ Positive & MFI \\
\hline $\mathrm{JHC7}$ & $\begin{array}{l}\text { 61-year old female } \\
\text { Primary sacral chordoma }\end{array}$ & A24 & 93.5 & 150 & 94.9 & 210 & 81.1 & 85.1 & 94.6 & 258 \\
\hline UM-Chor1 & $\begin{array}{l}\text { 64-year old male } \\
\text { Primary clival chordoma }\end{array}$ & $\begin{array}{l}\text { A2 } \\
\text { A3 }\end{array}$ & 98.7 & 79.5 & 98 & 107 & 47.4 & 24.3 & 99.1 & 196 \\
\hline $\mathrm{U}-\mathrm{CH} 2$ & $\begin{array}{l}\text { 72-year old female } \\
\text { Recurrent sacral chordoma }\end{array}$ & A11 & 54.5 & 37.4 & 91.5 & 94.1 & 79.8 & 94.9 & 95 & 189 \\
\hline MUG-Chor1 & $\begin{array}{l}\text { 54-year old female } \\
\text { Primary sacral chordoma }\end{array}$ & A11 & 73.8 & 75.4 & 92.6 & 118 & 49.8 & 54.4 & 94.6 & 108 \\
\hline
\end{tabular}

B.

JHC7

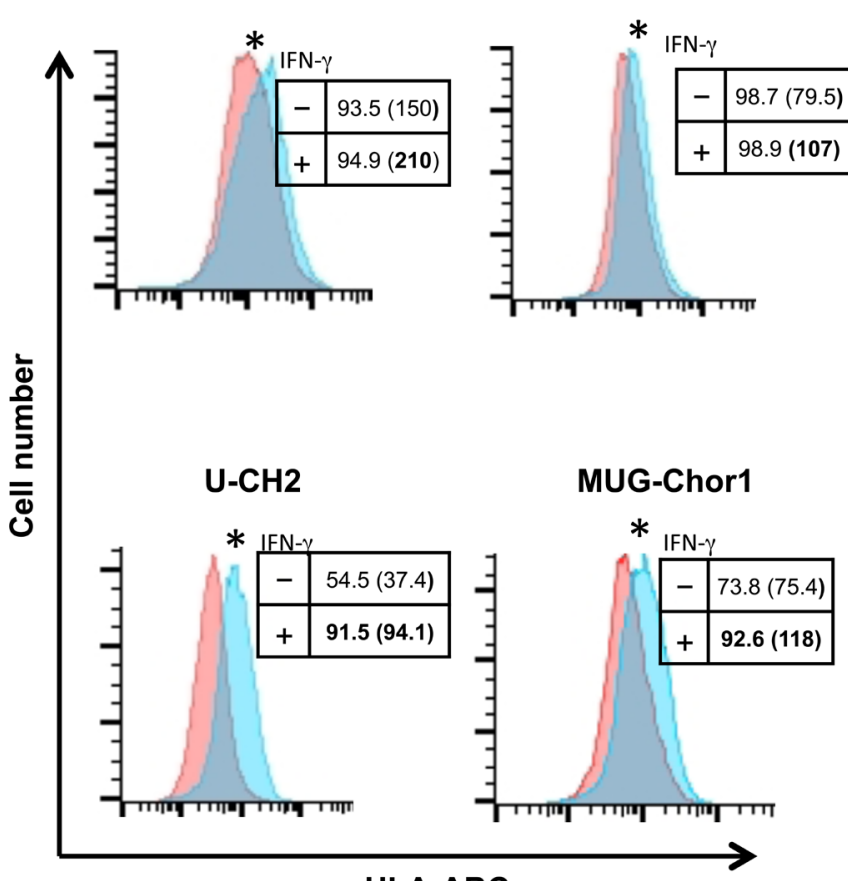

HLA-ABC UM-Chor1
C. JHC7

UM-Chor1

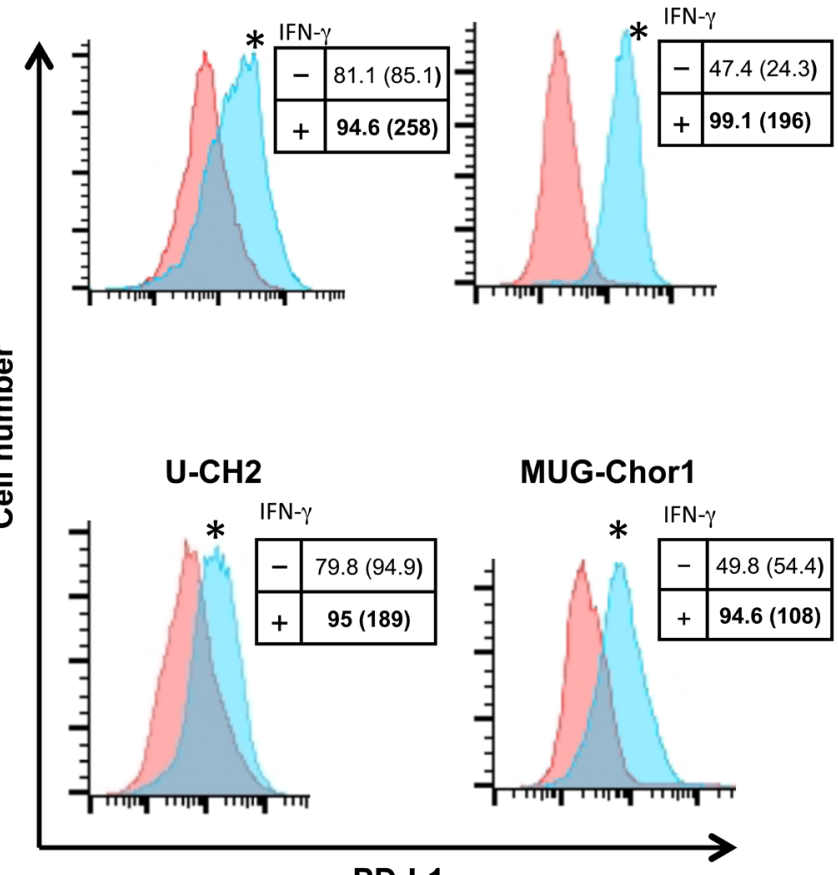

PD-L1

Figure 1: Treating chordoma cells with IFN- $\gamma$ upregulates MHC-I and PD-L1 expression. Chordoma cell lines established from 4 patients were treated with $50 \mathrm{ng} / \mathrm{mL}$ of IFN- $\gamma$ or untreated as control for $24 \mathrm{~h}$, then analyzed by flow cytometry. A. General characteristics of chordoma cell lines, surface expression of MHC-I (HLA-ABC) and PD-L1; percent positivity and MFI. B. Expression of HLA-ABC in chordoma cell lines treated with IFN- $\gamma$ (blue histograms) or untreated (pink histograms). C. Expression of PD-L1 in chordoma cell lines treated with IFN- $\gamma$ (blue histograms) or untreated (pink histograms). Insets: Numbers indicate $\%$ positive cells and MFI (parentheses). Values in bold denote an increase of $>10 \%$ relative to control cells. $*=$ statistical significance over control $(P<0.05)$. This experiment was repeated at least 2 times with similar results. 
treated with IFN- $\gamma$, avelumab markedly enhanced NK-cell lysis relative to isotype control in the following cell lines: JHC7 (7.56-fold; $P=0.001)$, UM-Chor1 (7.34-fold; $P<$ $0.001)$, U-CH2 (2.6 fold; $P=0.008)$, MUG-Chor1 (8.38fold; $P=0.0016)$. NK-cell lysis via ADCC occurs when CD16 (Fc $\gamma$ RIII) on NK effector cells interacts with the Fc portion of antibodies recognizing target cells [28]. The addition of CD16 neutralizing antibody inhibited NKcell lysis in all the cell lines, indicating that NK-cell lysis was mediated by ADCC (Figure 2). In sum, avelumab increases chordoma cells' sensitivity to NK-cell lysis via ADCC, and avelumab's efficacy is enhanced in chordoma cells that have IFN- $\gamma$-induced overexpression of PD-L1.

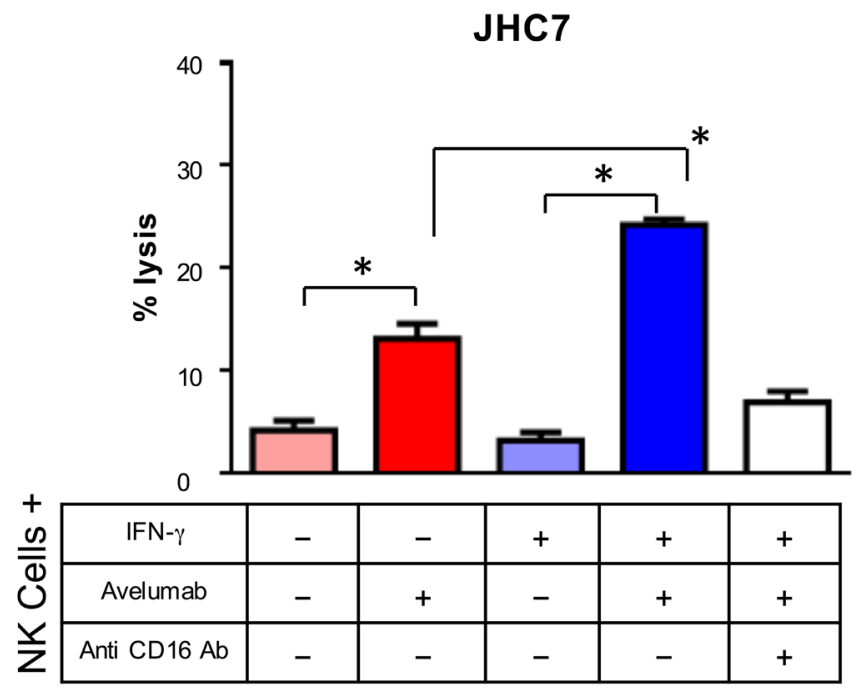

$\mathrm{U}-\mathrm{CH} 2$

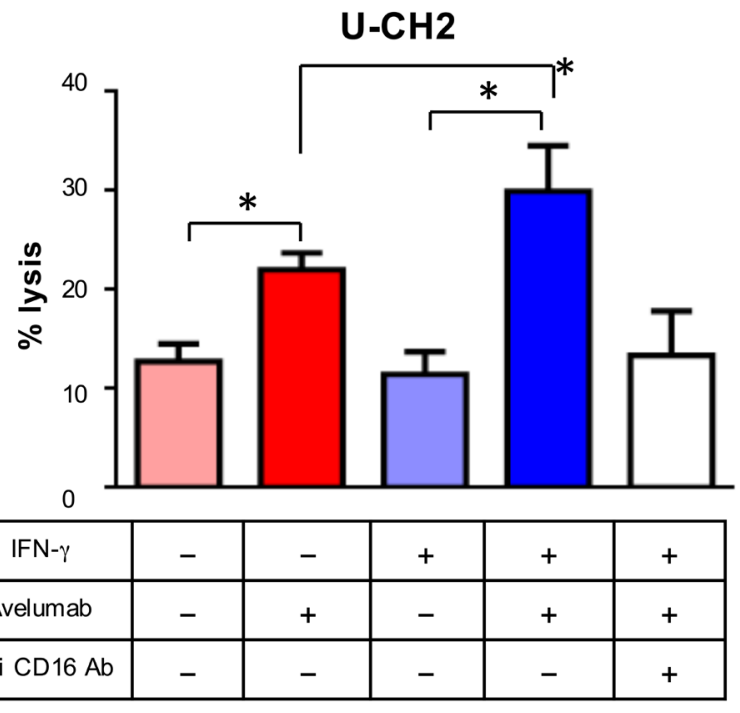

Tumor antigen-specific $\mathrm{CD8}^{+} \mathrm{T}$ cells increased avelumab-mediated sensitivity to ADCC

Having seen that IFN- $\gamma$ treatment upregulated PDL1 expression (Figure 1C) and increased sensitivity to ADCC (Figure 2), we sought to establish a model where IFN- $\gamma$ would be produced by tumor antigen-specific $\mathrm{CD}^{+} \mathrm{T}$ cells. We hypothesized that IFN $-\gamma$ released by tumor antigen-specific $\mathrm{CD}^{+} \mathrm{T}$ cells, either endogenous or vaccine-mediated, would upregulate PD-L1 expression on tumor cells, increasing their sensitivity to avelumabmediated ADCC (Figure 3A). To test this hypothesis, we
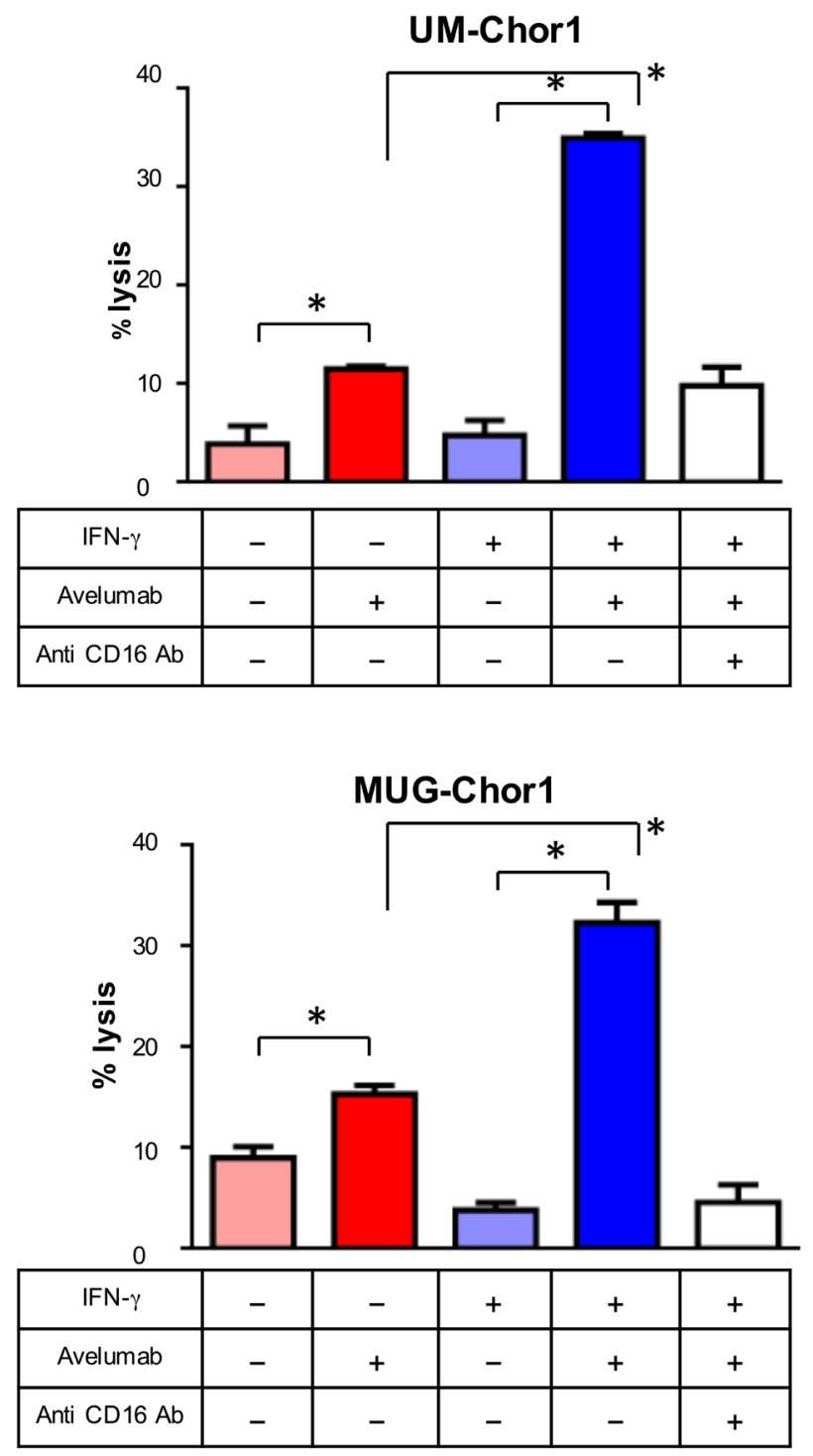

Figure 2: IFN- $\gamma$ treatment increased chordoma cells' sensitivity to NK-cell lysis via avelumab-mediated ADCC. ADCC assays were performed using 4 chordoma cell lines treated or untreated with IFN- $\gamma$, using normal donor NK cells as effector cells. Select groups of cells were incubated with avelumab and/or anti-CD16 antibody. Statistical analyses were done by Student's $t$ test. $*=P<0.05$, error bars indicate mean $\pm \mathrm{SD}$ for triplicate measurements. This experiment was repeated at least 2 times with similar results. 
A.

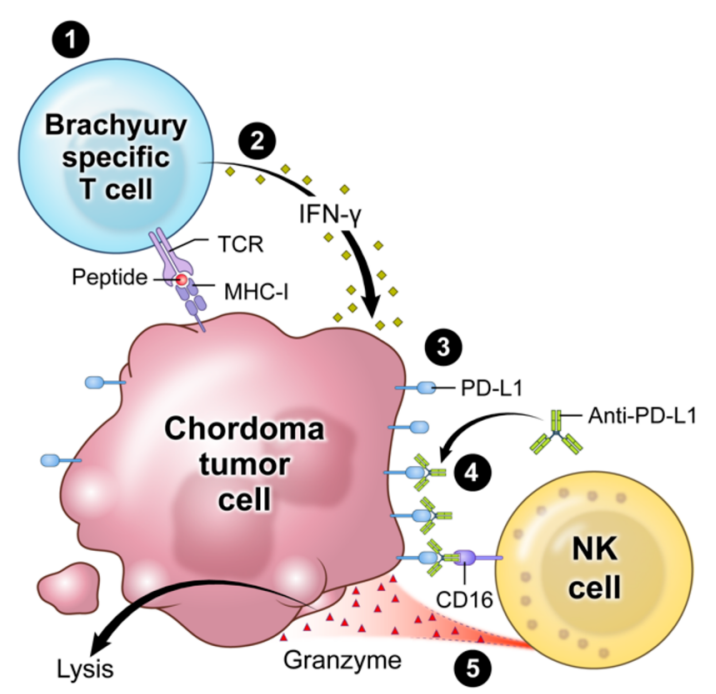

B. IFN- $\gamma$ concentration

\begin{tabular}{|c|c|c|c|}
\hline control & IFN- $\gamma$ & $\begin{array}{c}\text { Brachyury specific } \text { CD8 }^{+} \mathbf{T} \text { cell line } \\
\text { (Tp2A })\end{array}$ & Normal donor naïve $\mathbf{C D 8}^{+} \mathbf{T}$ cells \\
\hline$<3.76$ & $>2720$ & 1334.14 & 9.58 \\
\hline
\end{tabular}

C. PD-L1 expression

\begin{tabular}{|c|c|c|c|c|c|c|c|}
\hline \multicolumn{2}{|c|}{ control } & \multicolumn{2}{|c|}{ IFN- $\gamma$} & \multicolumn{2}{|c|}{$\begin{array}{l}\text { Brachyury specific CD8 }{ }^{+} T \text { cell line } \\
(\mathrm{Tp2A})\end{array}$} & \multicolumn{2}{|c|}{ Normal donor naïve $\mathrm{CD8}^{+} \mathrm{T}$ cells } \\
\hline$\%$ Positive & MFI & $\%$ Positive & MFI & $\%$ Positive & MFI & \% Positive & MFI \\
\hline 60.3 & 12.9 & 97 & 89.4 & 86 & 42.7 & 47.9 & 9.33 \\
\hline
\end{tabular}

D.

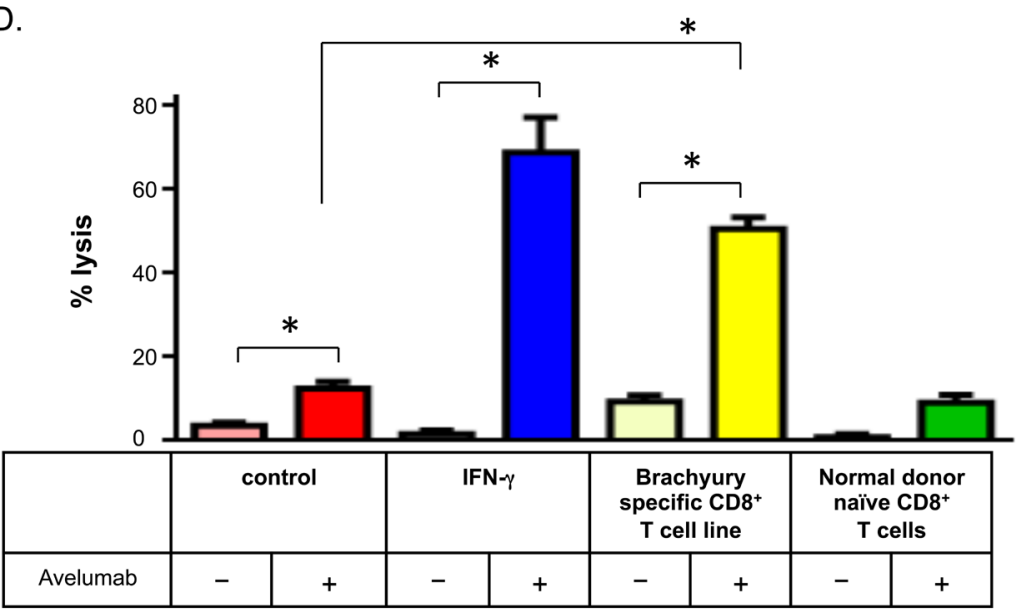

Figure 3: Brachyury-specific $\mathrm{CD8}^{+} \mathrm{T}$ cells increased chordoma cells' sensitivity to avelumab-mediated ADCC. A. Model of indirect enhancement of ADCC by tumor antigen-specific T cells: 1) brachyury-specific T-cell recognition of chordoma tumor; 2) induced IFN- $\gamma$ secretion; 3) PD-L1 upregulation; 4) increased binding of anti-PD-L1 (avelumab); and 5) enhanced NK cell-mediated killing of tumor (ADCC). UM-Chor1 cells were co-cultured for $24 \mathrm{~h}$ with brachyury-specific $\mathrm{CD}^{+} \mathrm{T}$ cells or naïve $\mathrm{T}$ cells isolated from PBMCs of a normal donor. As a positive control, UM-Chorl cells were treated or untreated with $50 \mathrm{ng} / \mathrm{mL}$ of IFN- $\gamma$ for $24 \mathrm{~h}$. B. Concentration of IFN- $\gamma(\mathrm{pg} / \mathrm{mL})$ in supernatant fluid following T cell/tumor cell co-incubation. C. Expression of PD-L1 in UM-Chor1 cells was analyzed by flow cytometry. Values in bold denote an increase of $>10 \%$ relative to vehicle control cells. D. ADCC assays were performed using UMChorl cells, with purified normal donor NK cells as effector cells. Select groups of cells were incubated with avelumab. Statistical analyses were done by Student's $t$ test. $*=P<0.05$, error bars indicate mean \pm SD for triplicate measurements. This experiment was repeated at least 2 times with similar results. 
first co-cultured tumor cells and tumor antigen-specific $\mathrm{CD}^{+} \mathrm{T}$ cells. Chordoma cells have been shown to express the transcription factor brachyury [29, 30], especially the UM-Chor1 cell line [19], which we confirmed (Supplemental Figure 2). To examine the response of brachyury-specific $\mathrm{CD}^{+} \mathrm{T}$ cells to chordoma cells, we co-cultured HLA-A2 ${ }^{+}$UM-Chor1 cells for $24 \mathrm{~h}$ with brachyury-specific HLA-matched $\mathrm{CD}^{+} \mathrm{T}$ cells or naïve $\mathrm{CD}^{+} \mathrm{T}$ cells isolated from HLA-matched peripheral blood mononuclear cells (PBMCs) from a normal donor as control $\mathrm{CD}^{+} \mathrm{T}$ cells. Brachyury-specific $\mathrm{CD}^{+} \mathrm{T}$ cells increased IFN- $\gamma$ production 140 -fold (1334.14 pg/ $\mathrm{mL}$ ) over naïve $\mathrm{CD}^{+} \mathrm{T}$ cells (Figure $3 \mathrm{~B}$ ). Moreover, interaction with brachyury-specific $\mathrm{CD}^{+} \mathrm{T}$ cells increased PD-L1 expression in UM-Chor1 cells 3.31-fold; naïve $\mathrm{CD}^{+} \mathrm{T}$ cells did not show increased PD-L1 expression (Figure 3C). Finally, we performed ADCC assays using co-cultured UM-Chor1 cells to assess the effect of $\mathrm{CD}^{+}$ $\mathrm{T}$ cells on their sensitivity to avelumab-mediated ADCC (Figure 3D). IFN- $\gamma$-treated cells increased avelumabmediated ADCC 5.5-foldover untreated cells $(P<0.0001)$. Similarly, UM-Chor1 cells co-cultured with brachyuryspecific $\mathrm{CD}^{+} \mathrm{T}$ cells increased avelumab-mediated ADCC 4.03-fold over untreated cells $(P<0.0001)$. Taken together, these results suggest that brachyury-specific $\mathrm{CD}^{+} \mathrm{T}$ cells increase PD-L1 expression on chordoma cells via IFN- $\gamma$ production, increasing chordoma cells' sensitivity to avelumab-mediated ADCC.

\section{Phenotypic signature of a residential CSC population in chordoma cell lines}

CSCs have been recognized in recent years as important players in the development of solid tumors. Cells with CSC characteristics are resistant to current treatment modalities including radiation and chemotherapy and are associated with poor treatment response rates and disease recurrence. Certain established tumor cell lines have been reported to harbor residential CSC populations. Previous studies have defined the CSC population in a single chordoma cell line, U-CH1, as expressing CD15 and CD133 [31]. We investigated the relative expression levels (mean fluorescence intensity; MFI) of CD24, CD133, $\mathrm{CD} 15$, and ALDH in the CD24 $4^{\text {high }} / \mathrm{CD} 133^{\text {high }}$ group in 4 chordoma cell lines (Figure 4A). Both CD15 and ALDH were markedly increased in the $\mathrm{CD} 24^{\text {high }} / \mathrm{CD} 133^{\text {high }}$ group, defined as the residential CSC population, compared to the non-CSC population (Figure 4A). As an example, the non-CSC population in JHC7 cells were CD24 (8633), CD133 (41), CD15 (233), and ALDH (145). These MFIs were markedly less than the MFIs observed in the CSC population. We observed similar MFIs for the non-CSC populations in the other chordoma cell lines. A residential CSC population was detectable in 4 of 4 cell lines, ranging from $6 \%-18 \%$ of the total population, as determined by CD24 and CD133 co-expression (Figure 4B). These data suggest that chordoma cells have a CSC subpopulation that can be identified by the stem cell markers CD24, CD133, CD15, and ALDH.

\section{Treating chordoma cells with IFN- $\gamma$ increases NK- cell killing of both CSC and non-CSC populations via ADCC}

To determine whether avelumab-mediated ADCC could increase CSC subpopulation killing, we stained UMChor 1 cells with the CSC markers CD24 and CD133 and treated them with or without IFN- $\gamma$. Treatment with IFN- $\gamma$ did not change the frequency of the CSC subpopulation (Figure 5A, 5B). Flow cytometric staining analyses of these cells showed a 5-fold increase in PD-L1 expression following IFN- $\gamma$ treatment (Figure 5B, inset). UM-Chor 1 cells treated with IFN- $\gamma$ were then subjected to an ADCC assay with avelumab, and the degree of cell death was determined by viability stain exclusion (Figure 5C). In this assay, we used untreated UM-Chor1 cells as a baseline for comparison to IFN- $\gamma$-treated UM-Chor1 cells that underwent ADCC. In the non-CSC group, ADCCmediated cell death was 1.7-fold higher (Figure 5C; $P<$ $0.001)$ than baseline cell death. Notably, ADCC-mediated cell death in the CSC group also had a significant increase (1.7-fold; $P<0.001)$ compared to cell death in the baseline CSC group. These data suggest that IFN- $\gamma$ increases PDL1 expression in the CSC subpopulation of chordoma cells, and that avelumab effectively increases ADCC of both the non-CSC and CSC subpopulations to the same degree.

\section{DISCUSSION}

Immunotherapy has become a standard treatment for patients with certain cancers. The PD-1 inhibitors nivolumab and pembrolizumab are FDA-approved for melanoma and lung cancer. Currently, many clinical trials of agents that block the PD-1/PD-L1 pathway are ongoing in a range of cancers. The finding of a significant correlation between PD-L1 expression levels in tumor tissue and responsiveness to PD-1 pathway blockade [10, 32] has led to the investigation of PD-L1 expression in a variety of cancers, with the goal of developing further applications of PD-1 pathway blockade [33-36]. Feng et al. reported that PD-L1 is expressed in chordoma tissue samples, especially metastatic tumors [14]. It has also been reported that PD-L1 expression can be upregulated by IFN- $\gamma$ in several cancers $[12,37]$. Previous studies showed that IFN- $\gamma$ could induce PD-L1 expression in the chordoma cell lines U-CH1, U-CH2, CH22, and JHC7 $[14,15]$. Here, we confirmed previous reports that PD- 
A.

Chordoma Cancer Stem Cell (CSC) Phenotypic Signature: CD24 ${ }^{+}, \mathrm{CD}_{133}{ }^{+}, \mathrm{CD}^{+} 5^{+}, \mathrm{ALDH}^{+}$

\begin{tabular}{|c|c|c|c|c|c|c|c|c|c|}
\hline \multirow{2}{*}{ Cell Line } & \multirow{2}{*}{$\begin{array}{c}\text { CSC \% of } \\
\text { Population }\end{array}$} & \multicolumn{2}{|c|}{ CD24 (MFI) } & \multicolumn{2}{c|}{ CD133 (MFI) } & \multicolumn{2}{c|}{ CD15 (MFI) } & \multicolumn{2}{|c|}{ ALDH (MFI) } \\
\cline { 3 - 10 } & & $\begin{array}{c}\text { Non- } \\
\text { CSC }\end{array}$ & CSC & $\begin{array}{c}\text { Non- } \\
\text { CSC }\end{array}$ & CSC & $\begin{array}{c}\text { Non- } \\
\text { CSC }\end{array}$ & CSC & $\begin{array}{c}\text { Non- } \\
\text { CSC }\end{array}$ & CSC \\
\hline JHC7 & 7 & 8633 & 29986 & 41 & 2026 & 233 & 883 & 145 & 2964 \\
\hline UM-Chor1 & 6 & 6439 & 11335 & 62 & 958 & 256 & 535 & 175 & 1389 \\
\hline U-CH2 & 18 & 21408 & 51115 & 89 & 1805 & 511 & 1325 & 291 & 2405 \\
\hline MUG-Chor1 & 6 & 6549 & 17835 & 45 & 2813 & 249 & 919 & 128 & 3565 \\
\hline
\end{tabular}

B.
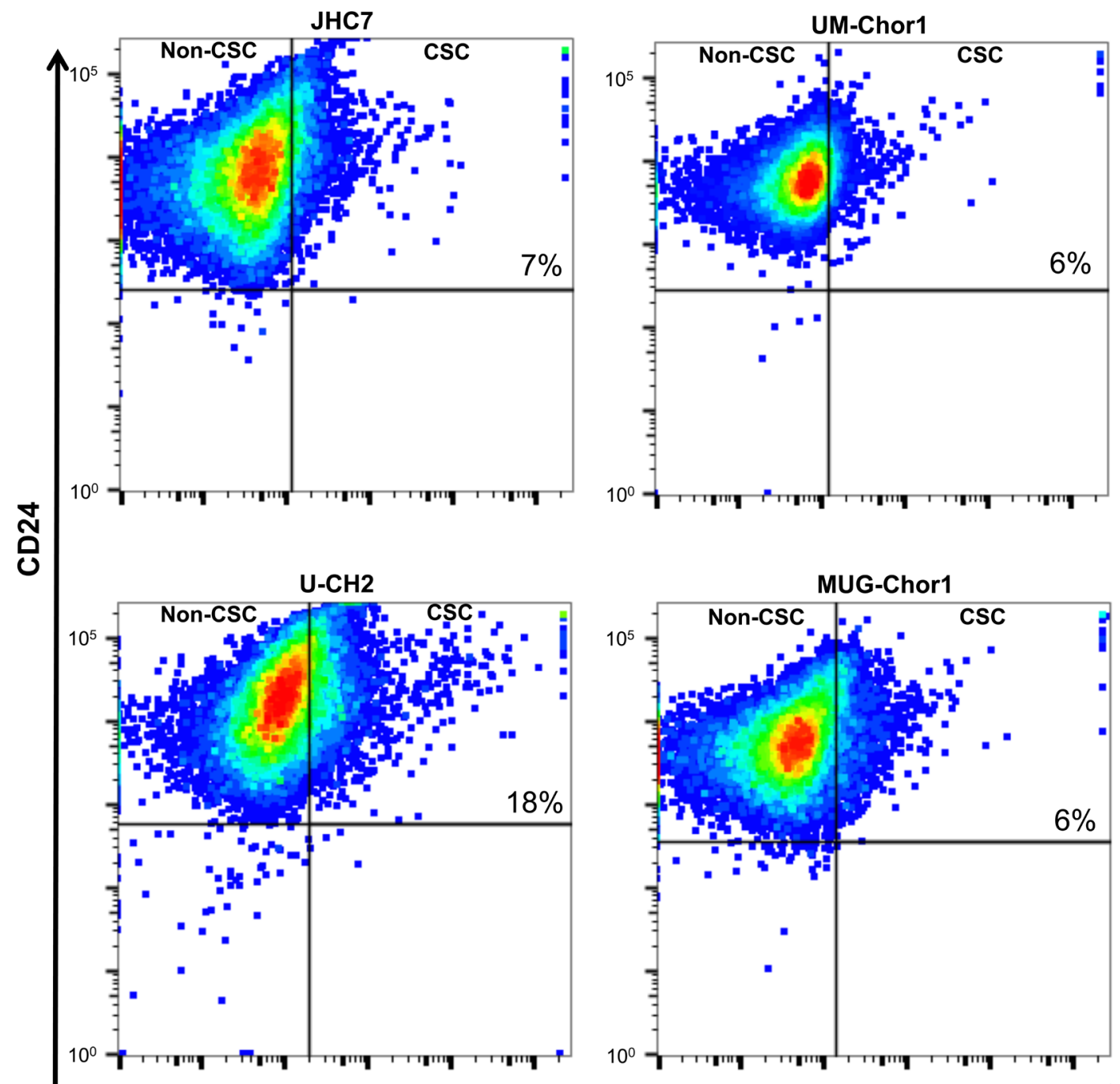

CD133

Figure 4: Phenotypic signature of a residential CSC population in chordoma cell lines. Four chordoma cell lines were analyzed for expression of CD24, CD133, CD15, and ALDH by flow cytometric analyses. A. Respective MFIs for each CSC marker studied. This experiment was repeated 3 times with similar results. B. Representative expression of CD24 and CD133 for each of the 4 chordoma cell lines. 
A.

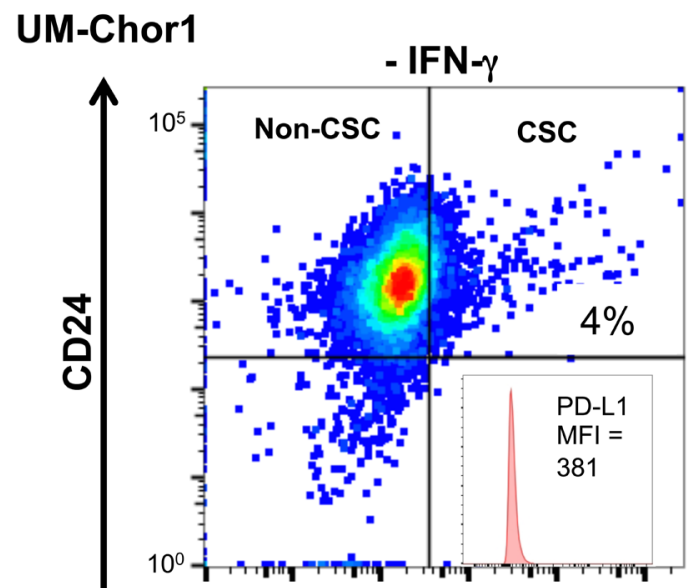

B.

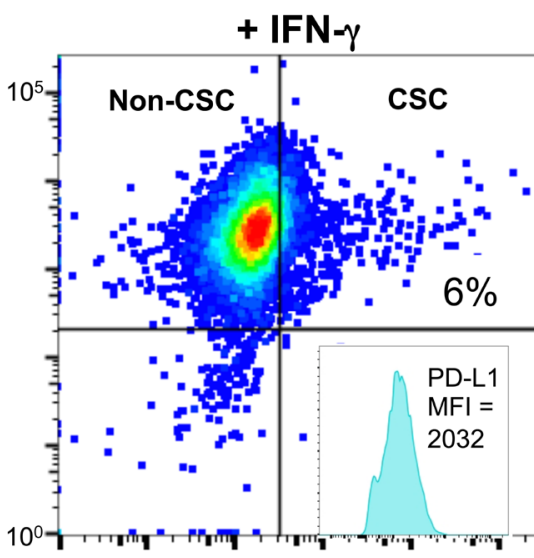

CD133

C.

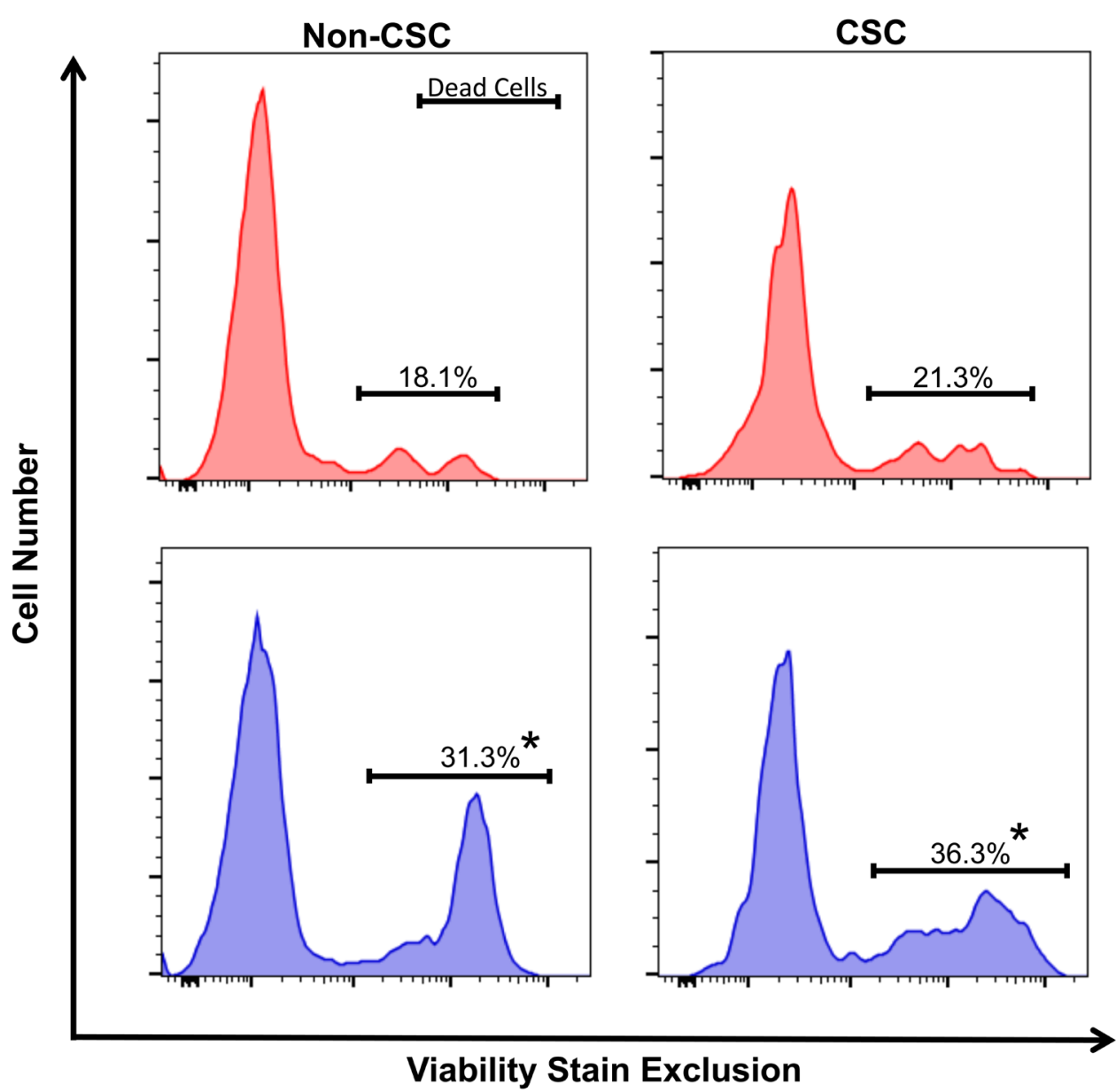

Figure 5: Treating chordoma cells with IFN- $\gamma$ increases NK-cell killing of both non-CSC and CSC populations via ADCC. Flow expression of CD24 and CD133 in a CSC subpopulation of UM-Chor1 cells treated A. without or B. with IFN- $\gamma$. Inset panels: PD-L1 expression on CSC populations. C. UM-Chor1 cells were (upper; red) untreated as baseline control or (lower; blue) treated with IFN- $\gamma$ and underwent avelumab-mediated ADCC assay. Cells were stained with a live/dead viability marker to determine cell death in non-CSC and CSC populations. * = statistical significance relative to control $(P<0.05)$. 
L1 expression was upregulated by IFN- $\gamma$ in U-CH2 and JHC7 (Figure 1) $[14,15]$. We extended these observations to include the chordoma cell lines UM-Chor1 and MUGChor1, and confirmed that they also expressed PD-L1, which was upregulated by IFN- $\gamma$ (Figures 1, 3, and 5).

The finding of PD-L1 expression in chordoma (Figure 1) suggested potential clinical benefit from PD-1/ PD-L1 pathway blockade. Several anti-PD-L1 antibodies have been generated and are being evaluated in ongoing phase II/III clinical trials. Of these agents, avelumab appears to be the only one that induces ADCC in NK cells. Previously, our group reported that avelumab enhanced ADCC in various cancer cell lines that express PD-L1 [13]. However, the potential of anti-PD-L1 antibody therapy for ADCC in chordoma has not previously been shown. It should be noted that chordoma cells expressed a relatively high baseline expression of PD-L1 which could be further increased with IFN- $\gamma$ (Figure 1). It has been reported that the overall cell-surface surface density of PD-L1 (as determined by, MFI) rather than the percentage of positive cells may be greater predictor or sensitivity to ADCC. Boyerinas et al., conducted flow cytometric analysis of a panel of 18 human tumor cell lines encompassing five different tumor types and showed that human carcinoma cell lines express a broad range of PD-L1 \% positive cells and PD-L1 cell surface densities. Moreover, those cell lines with the highest cell surface expression were the most sensitive to ADCC mediated by avelumab [13].

Here, we show that avelumab significantly increased NK-cell lysis via ADCC in 4 of 4 chordoma cell lines (Figure 2). Moreover, avelumab's efficacy is further enhanced in chordoma cells where treatment with IFN- $\gamma$ has induced overexpression of PD-L1 (Figure 2). It has also been reported that IFN- $\gamma$ produced by activated $\mathrm{CD}^{+} \mathrm{T}$ cells can upregulate PD-L1 expression on tumor cells $[38,39]$. A potential strategy for activating tumorrecognizing $\mathrm{T}$ cells is a vaccine encoding a tumor-specific antigen. Since chordoma expresses the transcription factor brachuyury [30], a rational strategy for treating chordoma may be a vaccine that encodes brachyury.

Historically, transcription factors have been considered undruggable targets [40] for standard cytotoxic agents, but other potential means of targeting brachyury have been proposed, including small inhibitory RNA, epigenetic modulation, and immune-based therapy [41, 42]. To date, the only attempts to target brachyury have been with 2 therapeutic cancer vaccines. Our group recently completed a phase I trial of GI-6301 (recombinant yeast-brachyury vaccine) that enrolled 11 patients with advanced chordoma [13]. An ongoing phase II clinical trial in chordoma patients is evaluating a brachyury vaccine in combination with radiation therapy. One patient had a confirmed radiographic partial response by RECIST, another had a mixed response, and the median progressionfree survival in the chordoma group was 8.3 months. The vaccine induced brachyury-specific T-cell responses in the majority of all patients enrolled and in the subset of patients enrolled with chordoma. There were no significant vaccine-related toxicities [43]. Notably, the 2 patients with evidence of tumor shrinkage both had radiotherapy within 3.5 months of enrolling on study. Given the low likelihood of radiographic response with radiotherapy alone in advanced-stage disease, our hypothesis was that radiotherapy had an immunomodulatory effect on chordoma cells, making them more amenable to $\mathrm{T}$ cellmediated killing.

To model a patient receiving a brachyury vaccine (Figure 3A), we co-incubated chordoma cells with brachyury-specific $\mathrm{CD} 8^{+} \mathrm{T}$ cells. The brachyury-specific $\mathrm{CD}^{+} \mathrm{T}$ cells recognized chordoma cells and increased PD-L1 expression on chordoma cells through the production of IFN- $\gamma$ (Figure 3B and 3C). This increased PD-L1 expression significantly increased the chordoma cells' sensitivity to avelumab-mediated ADCC of NK cells (Figure 3D). In a previous study we observed that radiation did not modulate $\mathrm{PD}-\mathrm{L} 1$ expression on tumor cell lines [44]. Similarly, chordoma cell lines (JHC7, UM-Chor1, U-CH2, and MUG-Chor1) exposed to 8 Gy radiation showed no increase in PD-L1 expression after $72 \mathrm{~h}$ (Supplemental Table 1). Radiation therapy has been reported to upregulate PD-L1 on tumors in-vivo, likely indirectly from the radiation induced inflammatory response. Future studies will focus on how to exploit PDL1 modulation in response to radiation. These observations suggest a rationale for treating additional cohorts of the ongoing phase II trial (NCT02383498) with avelumab.

It has been shown that MHC-I expression is increased by IFN- $\gamma$ and upregulated in cancer tissue $[16,17]$. Our study showed that IFN- $\gamma$ also increased expression of HLA-ABC in chordoma cells (Figure 1C). While some have suggested that increased MHC-I expression may induce resistance to NK-cell lysis, as NK cells discriminate between self and non-self by monitoring the expression of MHC-I molecules [45], increased expression of MHC-I has actually been shown to enhance sensitivity to cytotoxic T lymphocytes (CTLs) by upregulating antigen processing and presentation on tumor cells [17]. Our results indicate that chordoma cells treated with vaccine may have increased sensitivity not only to ADCC, but also to CTLs.

We assessed the molecular consequences of IFN- $\gamma$ induced gene expression by microarray analysis, focusing on UM-Chor1, which showed the greatest increase of IFN- $\gamma$-induced PD-L1 expression among the 4 chordoma cell lines (Figure 1C). The gene with the second highest upregulation, $C E B P D$, is a transcription factor that modulates many biological processes, including cell differentiation, motility, growth arrest, proliferation, and cell death. Though it was reported that $C E B P D$ was induced by IFN- $\gamma$ in certain cancers $[24,46], C E B P D$ functions both as a tumor suppressor and a tumor 
promoter [47]. Here we showed the predicted pathway of PD-L1 expression induced by IFN- $\gamma$, deduced from the results of microarray analysis. $C E B P D$ is induced by IFN- $\gamma$, which leads to inhibition of $M Y C$ and activation of TLR9, IL10, and TNF, and culminates in upregulation of PD-L1 (CD274) expression (Supplemental Figure 1C). This suggests that $C E B P D$ is potentially involved in the pathway of IFN- $\gamma$-induced PD-L1 expression in chordoma cells. This would block the innate immune response and result in tumor progression. Further investigation is needed to confirm the function of $C E B P D$ in chordoma cells.

Recently, CSCs have been recognized as critical to the development of solid tumors. CSCs have been reported to be largely resistant to treatments such as radiation and chemotherapy [48]. There have been concerted efforts to determine the markers that define CSCs in several cancers. It is noteworthy that the expression of CSC surface markers is tissue type-specific. For example, the CSC surface markers $\mathrm{CD} 44^{+}$and $\mathrm{CD} 24^{-}$were defined in breast cancer, $\mathrm{CD} 20^{+}$and $\mathrm{ABCB}^{+}$in melanoma, and $\mathrm{EpCAM}^{+}$, $\mathrm{CD} 44^{+}$, and $\mathrm{CD}_{166^{+}}$in colon cancer [49]. In an effort to define the phenotypic signature of chordoma CSCs, we observed that CD15 and ALDH were also highly expressed in $\mathrm{CD} 24^{\text {high }} / \mathrm{CD} 133^{\text {high }}$ (Figure 4A). ALDH has been widely used as a CSC marker in various cancer types [50]. Thus, we found that $\mathrm{CD} 24^{\text {high }} / \mathrm{CD} 133^{\text {high }}$ cells could be defined as a CSC subpopulation in chordoma cells. Moreover, CD24 ${ }^{\text {high }} / \mathrm{CD} 133^{\text {high }}$ cells showed high expression of CD15. These data confirm and extend previous findings that $\mathrm{CD} 15$ and $\mathrm{CD} 133$ were candidates for CSC markers in chordoma, using a U-CH1 cell line [31]. Our data suggest that, as the stem markers, CD24, CD133, CD15, and ALDH could identify a residential CSC subpopulation in chordoma. However, the potential of immunotherapy for CSCs remains controversial [51]. Previous studies showed that breast CSCs had resistance to NK killing due to reduced expression of the ligands for NKG2D, the stimulatory NK cell receptor [52]. On the other hand, Tallerico et al. reported that colorectal CSCs express higher levels of ligand for the natural cytotoxicity receptors that mediate NK-cell killing [53]. Thus, we investigated the possibility of treating chordoma CSCs with immunotherapy. IFN- $\gamma$ treatment upregulated PD-L1 expression in the CSC population of chordoma (Figure 5A, 5B), suggesting PD-L1 blockade as a potential treatment for chordoma CSCs. Furthermore, the chordoma CSCs were killed by avelumab-mediated ADCC to the same degree as the non-CSCs (Figure 5C).

Our study is the first to show that PD-L1 expression induced by IFN- $\gamma$ increases chordoma cells' sensitivity to NK-cell lysis via avelumab-mediated ADCC. Moreover, in a model of a patient receiving a tumor antigen-specific vaccine, brachyury-specific CD $8^{+} \mathrm{T}$ cells increased $\mathrm{PD}-$ L1 expression on chordoma cells through the production of IFN- $\gamma$, increasing the sensitivity of chordoma cells to avelumab-mediated ADCC. We also identified the residential CSC population in chordoma cells and showed that they were killed by avelumab-mediated ADCC. Our findings indicate the potential of avelumab to enable endogenous NK cells to kill chordoma cells via ADCC, as well as the potential of combination therapy, such as a T-cell vaccine and avelumab, to enhance NK-cell killing of chordoma cells via ADCC. Our findings suggest that while chordoma is resistant to conventional therapies such as radiotherapy and chemotherapy, immune-mediated therapy may have clinical benefit for patients with chordoma.

\section{MATERIALS AND METHODS}

\section{Cell culture and reagents}

Chordoma cell lines JHC7 and UM-Chor1 were obtained from the Chordoma Foundation (Durham, NC). The chordoma cell lines U-CH2 (ATCC ${ }^{\circledR}$ CRL-3218 ${ }^{\mathrm{TM}}$ ) and MUG-Chor 1 (ATCC ${ }^{\circledR}$ CRL-3219 ${ }^{\mathrm{TM}}$ ) were obtained from American Type Culture Collection (Manassas, VA). All cells were passaged for fewer than 6 months. JHC7 cells were maintained in DMEM/F12 medium supplemented with $10 \%$ fetal bovine serum and $1 \%$ penicillin/streptomycin. UM-Chorl cells were maintained in Iscove's modification of DMEM and RPMI1640 medium (4:1), supplemented with $10 \%$ fetal bovine serum, $1 \%$ penicillin/streptomycin, and nonessential amino acids. U-CH2 and MUG-Chor1 cells were maintained in Iscove's modification of DMEM and RPMI1640 medium (4:1), supplemented with $10 \%$ fetal bovine serum and $1 \%$ penicillin/streptomycin. In addition, MUG-Chor1 cells required $10 \mu \mathrm{g} / \mathrm{mL}$ human insulin. PBMCs from healthy donors were obtained from the NIH Clinical Center Blood Bank (NCT00001846).

The anti-PD-L1 mAb avelumab and matching IgG1 isotype control were obtained from EMD Serono as part of a Cooperative Research and Development Agreement with the Laboratory of Tumor Immunology and Biology, National Cancer Institute.

\section{Flow cytometry}

To assess the effect of IFN- $\gamma$ on the cell-surface phenotype of chordoma cells, cells were untreated or treated with $50 \mathrm{ng} / \mathrm{mL}$ of IFN- $\gamma$ (R\&D Systems, Minneapolis, MN) for $24 \mathrm{~h}$. Cells were then harvested and stained with the following antibodies: HLA-ABCFITC (BD Biosciences, San Jose, CA), PD-L1-APC (clone 29E.2A3; BioLegend, San Diego, CA), CD133PE (Miltenyi Biotec, San Diego, CA), CD24-PerCP-Cy 5.5 (BD Biosciences), CD15-V450 (BD Biosciences), and ALDHA1-FITC (USBiological, Salem, MA). Cell viability was examined using far red fluorescent reactive 
dye (Thermo Fisher, Waltham, MA). Cells were incubated with the antibodies for $30 \mathrm{~min}$ at $4{ }^{\circ} \mathrm{C}$, acquired on a FACSCalibur flow cytometer or FACSVerse (Becton Dickinson, Franklin Lakes, NJ), and analyzed using FlowJo software (TreeStar, Inc., Ashland, OR). Isotype control staining was $<5 \%$ for all samples analyzed.

\section{Microarray analysis and statistical analysis}

UM-Chor1 cells were left untreated or treated with $50 \mathrm{ng} / \mathrm{mL}$ of IFN- $\gamma$ for $24 \mathrm{~h}$. Cells were then harvested and total RNA was isolated using the RNAeasy Plus minikit (Qiagen, Valencia, CA). $100 \mathrm{ng}$ of RNA was reverse transcribed and amplified using a WT expression kit (Ambion, Austin, TX). Sense strand cDNA was fragmented and labeled using a WT terminal labeling kit (Affymetrix, Santa Clara, CA). Three replicates of each group were hybridized to the Human Gene ST 2.0 GeneChip (Affymetrix) and scanned on the GeneChip scanner 3000 (Affymetrix). Data were collected using Affymetrix AGCC software.

Microarray data are available in the GEO under accession number GSE77732. Statistical and clustering analysis for the microarray experiment was performed with Partek Genomics Suite software (St. Louis, MO) using an RMA normalization algorithm. Differentially expressed genes were identified by ANOVA. Genes that were up- or downregulated $>1.5$-fold with a $P<0.05$ were considered significant. Significant genes were analyzed for enrichment of pathways using Ingenuity Pathway Analysis software (Qiagen, Redwood City, CA).

\section{Antibody-dependent cellular cytotoxicity assay}

The ADCC assay was performed as previously reported [13] with indicated modifications. Cells were left untreated or treated with $50 \mathrm{ng} / \mathrm{mL}$ of IFN- $\gamma$ for 24 h. Cells were then harvested and labeled with ${ }^{111} \mathrm{In}$. Cells were plated as targets at 2,000 cells/well in 96-well roundbottom culture plates and incubated with $2 \mu \mathrm{g} / \mathrm{mL}$ of avelumab or control isotype antibody at room temperature for $30 \mathrm{~min}$. NK cells were added at 100,000 cells/well at an effector-to-target (E:T) ratio of 50:1. After $4 \mathrm{~h}$, supernatants were harvested and analyzed for the presence of ${ }^{111}$ In using a WIZARD2 Automatic Gamma Counter (PerkinElmer, Waltham, MA). Spontaneous release was determined by incubating target cells without effector cells, and complete lysis was determined by incubation with $0.05 \%$ Triton X-100. Experiments were carried out in triplicate. Specific ADCC lysis was determined using the following equation: Percent lysis $=[($ experimental $\mathrm{cpm}$ spontaneous cpm) / (complete cpm - spontaneous cpm)] x 100 .

To verify that CD16 (Fc $\gamma$ RIII) on NK cells engage avelumab-mediated ADCC, CD16 mAb was used to block
CD16. NK cells were incubated with $2 \mu \mathrm{g} / \mathrm{mL}$ of CD16 $\mathrm{mAb}$ (clone B73.1; eBioscience, San Diego, CA) for $2 \mathrm{~h}$ before being added to target cells.

To examine the relationship between a CSC subpopulation and ADCC activity, UM-Chor1 cells were left untreated or treated with $50 \mathrm{ng} / \mathrm{mL}$ of IFN- $\gamma$ for $24 \mathrm{~h}$. Cells were then plated as targets at 50,000 cells/well in 6-well round-bottom culture plates and incubated with 2 $\mu \mathrm{g} / \mathrm{mL}$ of avelumab at room temperature for $30 \mathrm{~min}$. NK cells were added at 2500,000 cells/well at an E:T ratio of 50:1. After $4 \mathrm{~h}$, tumor cells were harvested and stained with antibodies for flow cytometry.

\section{Co-culture of chordoma cells and $T$ cells}

The HLA-A2-restricted brachyury-specific CD8 ${ }^{+}$ CTL line (Tp2A) recognizes the brachyury epitope WLLPGTSTL (T-p2) [54]. Normal donor CD8 ${ }^{+}$T cells were isolated from normal donor HLA-A2 ${ }^{+}$PBMCs using the Human $\mathrm{CD}^{+} \mathrm{T}$ Cell Isolation (negative selection) Kit 130-096-495 (Miltenyi Biotec) per the manufacturer's protocol.

UM-Chor1 cells were co-cultured in 12-well plates with $\mathrm{Tp} 2 \mathrm{~A}$ or normal donor $\mathrm{CD}^{+} \mathrm{T}$ cells at a tumor cell/ $\mathrm{CD}^{+} \mathrm{T}$ cell ratio of $2: 1$. As a positive or negative control, UM-Chor1 cells were left untreated or treated with 50 $\mathrm{ng} / \mathrm{mL}$ of IFN- $\gamma$ for $24 \mathrm{~h}$. After a $24-\mathrm{h}$ co-culture, the supernatant fluid was harvested and the concentration of IFN- $\gamma$ was measured using a multiplex cytokine/ chemokine kit (Meso Scale Discovery, Gaithersburg, MD). Tumor cells were harvested and used as a target for the ADCC assay, as described above, and stained with PDL1 antibody for flow cytometry.

\section{Western blot analysis}

The Western blot was performed as previously described [55] with indicated modifications. Protein lysate was extracted from UM-Chor1 cells. The primary antibodies used were monoclonal rabbit antibody (mAb 54-1, $1 \mu \mathrm{g} / \mathrm{mL}$ ) against human brachyury [29] and GAPDH (Cell Signaling Technology, Danvers, MA).

\section{Statistical analysis}

Significant differences in the distribution of data acquired by flow cytometry analysis were determined by the Kolmogorov-Smirnov test using FlowJo software (TreeStar, Inc.). Significant differences in the distribution of data acquired by ADCC assays were determined by paired Student's $t$ test with a 2-tailed distribution and reported as $P$ values, using Prism 6.0f software (GraphPad Software Inc., La Jolla, CA). 


\section{ACKNOWLEDGMENTS}

The authors thank Dr. Peter Kim and Dr. Anthony Malamas for helpful suggestions and technical assistance, Marion Taylor for excellent technical assistance, and Bonnie L. Casey for editorial assistance in the preparation of this manuscript.

\section{FUNDING}

This research was supported by the Intramural Research Program of the Center for Cancer Research, National Cancer Institute, National Institutes of Health, as well as through a cooperative research and development aggrement (CRADA) betwwen Emd Sereno and the NCI.

\section{CONFLICTS OF INTEREST}

The authors declare no conflicts of interest.

\section{REFERENCES}

1. Chugh R, Tawbi H, Lucas DR, Biermann JS, Schuetze SM and Baker LH. Chordoma: the nonsarcoma primary bone tumor. The oncologist. 2007; 12:1344-1350.

2. Walcott BP, Nahed BV, Mohyeldin A, Coumans JV, Kahle KT and Ferreira MJ. Chordoma: current concepts, management, and future directions. The Lancet Oncology. 2012; 13:e69-76.

3. Stacchiotti S and Sommer J. Building a global consensus approach to chordoma: a position paper from the medical and patient community. The Lancet Oncology. 2015; 16:e71-83

4. Vujovic S, Henderson S, Presneau N, Odell E, Jacques TS, Tirabosco R, Boshoff C and Flanagan AM. Brachyury, a crucial regulator of notochordal development, is a novel biomarker for chordomas. J Pathol. 2006; 209:157-165.

5. Shen J, Li CD, Yang HL, Lu J, Zou TM, Wang DL and Deng M. Classic chordoma coexisting with benign notochordal cell rest demonstrating different immunohistological expression patterns of brachyury and galectin-3. Journal of clinical neuroscience. 2011; 18:96-99.

6. Yang XR, Ng D, Alcorta DA, Liebsch NJ, Sheridan E, Li S, Goldstein AM, Parry DM and Kelley MJ. T (brachyury) gene duplication confers major susceptibility to familial chordoma. Nature genetics. 2009; 41:1176-1178.

7. Presneau N, Shalaby A, Ye H, Pillay N, Halai D, Idowu B, Tirabosco R, Whitwell D, Jacques TS, Kindblom LG, Bruderlein S, Moller P, Leithner A, Liegl B, Amary FM, Athanasou NN, et al. Role of the transcription factor $\mathrm{T}$ (brachyury) in the pathogenesis of sporadic chordoma: a genetic and functional-based study. The Journal of pathology. 2011; 223:327-335.

8. Nelson AC, Pillay N, Henderson S, Presneau N, Tirabosco
R, Halai D, Berisha F, Flicek P, Stemple DL, Stern CD, Wardle FC and Flanagan AM. An integrated functional genomics approach identifies the regulatory network directed by brachyury (T) in chordoma. The Journal of pathology. 2012; 228:274-285.

9. Topalian SL, Hodi FS, Brahmer JR, Gettinger SN, Smith DC, McDermott DF, Powderly JD, Carvajal RD, Sosman JA, Atkins MB, Leming PD, Spigel DR, Antonia SJ, Horn L, Drake CG, Pardoll DM, et al. Safety, activity, and immune correlates of anti-PD-1 antibody in cancer. The New England journal of medicine. 2012; 366:2443-2454.

10. Herbst RS, Soria JC, Kowanetz M, Fine GD, Hamid O, Gordon MS, Sosman JA, McDermott DF, Powderly JD, Gettinger SN, Kohrt HE, Horn L, Lawrence DP, Rost S, Leabman M, Xiao Y, et al. Predictive correlates of response to the anti-PD-L1 antibody MPDL3280A in cancer patients. Nature. 2014; 515:563-567.

11. Motzer RJ, Rini BI, McDermott DF, Redman BG, Kuzel TM, Harrison MR, Vaishampayan UN, Drabkin HA, George S, Logan TF, Margolin KA, Plimack ER, Lambert AM, Waxman IM and Hammers HJ. Nivolumab for Metastatic Renal Cell Carcinoma: Results of a Randomized Phase II Trial. Journal of clinical oncology. 2015; 33:14301437.

12. Topalian SL, Drake CG and Pardoll DM. Immune checkpoint blockade: a common denominator approach to cancer therapy. Cancer cell. 2015; 27:450-461.

13. Boyerinas B, Jochems C, Fantini M, Heery CR, Gulley JL, Tsang KY and Schlom J. Antibody-Dependent Cellular Cytotoxicity Activity of a Novel Anti-PD-L1 Antibody Avelumab (MSB0010718C) on Human Tumor Cells. Cancer immunology research. 2015; 3:1148-1157.

14. Feng Y, Shen J, Gao Y, Liao Y, Cote G, Choy E, Chebib I, Mankin H, Hornicek F and Duan Z. Expression of programmed cell death ligand 1 (PD-L1) and prevalence of tumor-infiltrating lymphocytes (TILs) in chordoma. Oncotarget. 2015; 6:11139-11149. doi:10.18632/ oncotarget. 3576 .

15. Mathios D, Ruzevick J, Jackson CM, Xu H, Shah S, Taube JM, Burger PC, McCarthy EF, Quinones-Hinojosa A, Pardoll DM and Lim M. PD-1, PD-L1, PD-L2 expression in the chordoma microenvironment. Journal of neurooncology. 2015; 121:251-259.

16. Torres MJ, Ruiz-Cabello F, Skoudy A, Berrozpe G, Jimenez P, Serrano A, Real FX and Garrido F. Loss of an HLA haplotype in pancreas cancer tissue and its corresponding tumor derived cell line. Tissue antigens. 1996; 47:372-381.

17. Leone P, Shin EC, Perosa F, Vacca A, Dammacco F and Racanelli V. MHC class I antigen processing and presenting machinery: organization, function, and defects in tumor cells. Journal of the National Cancer Institute. 2013; 105:1172-1187.

18. Hsu W, Mohyeldin A, Shah SR, ap Rhys CM, Johnson LF, Sedora-Roman NI, Kosztowski TA, Awad OA, McCarthy EF, Loeb DM, Wolinsky JP, Gokaslan ZL and Quinones- 
Hinojosa A. Generation of chordoma cell line JHC7 and the identification of Brachyury as a novel molecular target. Journal of neurosurgery. 2011; 115:760-769.

19. Owen JH, Wang AC and M. AW. Establishment and characterization of two novel human chordoma cell lines. Meeting abstract from the 2014 Annual meeting of the a century of progress in head \& neck cancer. 2014.

20. Bruderlein S, Sommer JB, Meltzer PS, Li S, Osada T, Ng D, Moller P, Alcorta DA and Kelley MJ. Molecular characterization of putative chordoma cell lines. Sarcoma. 2010; 2010:630129.

21. Rinner B, Froehlich EV, Buerger K, Knausz H, Lohberger B, Scheipl S, Fischer C, Leithner A, Guelly C, Trajanoski $\mathrm{S}$, Szuhai $\mathrm{K}$ and Liegl B. Establishment and detailed functional and molecular genetic characterisation of a novel sacral chordoma cell line, MUG-Chor1. International journal of oncology. 2012; 40:443-451.

22. Mauvezin C, Sancho A, Ivanova S, Palacin M and Zorzano A. DOR undergoes nucleo-cytoplasmic shuttling, which involves passage through the nucleolus. FEBS letters. 2012; 586:3179-3186.

23. Tsai VW, Mohammad MG, Tolhurst O, Breit SN, Sawchenko PE and Brown DA. CCAAT/enhancer binding protein-delta expression by dendritic cells regulates CNS autoimmune inflammatory disease. The Journal of neuroscience. 2011; 31:17612-17621.

24. Valente T, Straccia M, Gresa-Arribas N, Dentesano G, Tusell JM, Serratosa J, Mancera P, Sola C and Saura J. CCAAT/enhancer binding protein delta regulates glial proinflammatory gene expression. Neurobiology of aging. 2013; 34:2110-2124.

25. Furuse M, Fujita K, Hiiragi T, Fujimoto $\mathrm{K}$ and Tsukita S. Claudin-1 and -2: novel integral membrane proteins localizing at tight junctions with no sequence similarity to occludin. The Journal of cell biology. 1998; 141:1539-1550.

26. Suzuki $\mathrm{T}$, Yoshinaga $\mathrm{N}$ and Tanabe $\mathrm{S}$. Interleukin-6 (IL-6) regulates claudin-2 expression and tight junction permeability in intestinal epithelium. The Journal of biological chemistry. 2011; 286:31263-31271.

27. Solimini NL, Liang AC, Xu C, Pavlova NN, Xu Q, Davoli T, Li MZ, Wong KK and Elledge SJ. STOP gene Phactr4 is a tumor suppressor. Proceedings of the National Academy of Sciences of the United States of America. 2013; 110:E407-414.

28. Anegon I, Cuturi MC, Trinchieri G and Perussia B. Interaction of $\mathrm{Fc}$ receptor (CD16) ligands induces transcription of interleukin 2 receptor (CD25) and lymphokine genes and expression of their products in human natural killer cells. The Journal of experimental medicine. 1988; 167:452-472.

29. Hamilton DH, Litzinger MT, Jales A, Huang B, Fernando RI, Hodge JW, Ardiani A, Apelian D, Schlom J and Palena C. Immunological targeting of tumor cells undergoing an epithelial-mesenchymal transition via a recombinant brachyury-yeast vaccine. Oncotarget. 2013; 4:1777-1790. doi:10.18632/oncotarget.1295.

30. Miettinen M, Wang Z, Lasota J, Heery C, Schlom J and Palena C. Nuclear Brachyury Expression Is Consistent in Chordoma, Common in Germ Cell Tumors and Small Cell Carcinomas, and Rare in Other Carcinomas and Sarcomas: An Immunohistochemical Study of 5229 Cases. The American journal of surgical pathology. 2015; 39:13051312.

31. Aydemir E, Bayrak OF, Sahin F, Atalay B, Kose GT, Ozen M, Sevli S, Dalan AB, Yalvac ME, Dogruluk T and Ture U. Characterization of cancer stem-like cells in chordoma. Journal of neurosurgery. 2012; 116:810-820.

32. Brahmer JR, Drake CG, Wollner I, Powderly JD, Picus J, Sharfman WH, Stankevich E, Pons A, Salay TM, McMiller TL, Gilson MM, Wang C, Selby M, Taube JM, Anders R, Chen L, et al. Phase I study of single-agent anti-programmed death-1 (MDX-1106) in refractory solid tumors: safety, clinical activity, pharmacodynamics, and immunologic correlates. Journal of clinical oncology. 2010; 28:3167-3175.

33. Chen DS, Irving BA and Hodi FS. Molecular pathways: next-generation immunotherapy_-inhibiting programmed death-ligand 1 and programmed death-1. Clinical cancer research. 2012; 18:6580-6587.

34. Nomi T, Sho M, Akahori T, Hamada K, Kubo A, Kanehiro H, Nakamura S, Enomoto K, Yagita H, Azuma M and Nakajima Y. Clinical significance and therapeutic potential of the programmed death-1 ligand/programmed death-1 pathway in human pancreatic cancer. Clinical cancer research. 2007; 13:2151-2157.

35. Mittendorf EA, Philips AV, Meric-Bernstam F, Qiao N, Wu Y, Harrington S, Su X, Wang Y, Gonzalez-Angulo AM, Akcakanat A, Chawla A, Curran M, Hwu P, Sharma P, Litton JK, Molldrem JJ, et al. PD-L1 expression in triplenegative breast cancer. Cancer immunology research. 2014; 2:361-370

36. Sabatier R, Finetti P, Mamessier E, Adelaide J, Chaffanet M, Ali HR, Viens P, Caldas C, Birnbaum D and Bertucci F. Prognostic and predictive value of PDL1 expression in breast cancer. Oncotarget. 2015; 6:5449-5464. doi:10.18632/oncotarget.3216.

37. Dong H, Strome SE, Salomao DR, Tamura H, Hirano F, Flies DB, Roche PC, Lu J, Zhu G, Tamada K, Lennon VA, Celis E and Chen L. Tumor-associated B7-H1 promotes T-cell apoptosis: a potential mechanism of immune evasion. Nature medicine. 2002; 8:793-800.

38. Spranger S, Spaapen RM, Zha Y, Williams J, Meng Y, Ha TT and Gajewski TF. Up-regulation of PD-L1, IDO, and $\mathrm{T}$ (regs) in the melanoma tumor microenvironment is driven by CD8(+) T cells. Science translational medicine. 2013; 5:200ra116.

39. Abiko K, Matsumura N, Hamanishi J, Horikawa N, Murakami R, Yamaguchi K, Yoshioka Y, Baba T, Konishi I and Mandai M. IFN-gamma from lymphocytes induces PD- 
L1 expression and promotes progression of ovarian cancer. British journal of cancer. 2015; 112:1501-1509.

40. Yan $\mathrm{C}$ and Higgins PJ. Drugging the undruggable: transcription therapy for cancer. Biochimica et biophysica acta. 2013 ; 1835:76-85.

41. Hamilton DH, Litzinger MT, Fernando RI, Huang B and Palena C. Cancer vaccines targeting the epithelialmesenchymal transition: tissue distribution of brachyury and other drivers of the mesenchymal-like phenotype of carcinomas. Seminars in oncology. 2012; 39:358-366.

42. Palena C, Polev DE, Tsang KY, Fernando RI, Litzinger M, Krukovskaya LL, Baranova AV, Kozlov AP and Schlom J. The human T-box mesodermal transcription factor Brachyury is a candidate target for T-cell-mediated cancer immunotherapy. Clinical cancer research. 2007; 13:24712478.

43. Heery CR, Singh BH, Rauckhorst M, Marte JL, Donahue RN, Grenga I, Rodell TC, Dahut W, Arlen PM, Madan RA, Schlom J and Gulley JL. Phase I Trial of a YeastBased Therapeutic Cancer Vaccine (GI-6301) Targeting the Transcription Factor Brachyury. Cancer immunology research. 2015; 3:1248-1256.

44. Gameiro SR, Malamas AS, Bernstein MB, Tsang KY, Vassantachart A, Sahoo N, Tailor R, Pidikiti R, Guha CP, Hahn S, M., Krishnan S and Hodge JW. Tumor Cells Surviving Exposure to Proton or Photon Radiation Share a Common Immunogenic Modulation Signature, Rendering Them More Sensitive to $\mathrm{T}$ Cell-Mediated Killing. International Journal of Radiation Oncology, Biology, Physics. 2016:In-Press.

45. Ljunggren HG and Malmberg KJ. Prospects for the use of NK cells in immunotherapy of human cancer. Nature reviews Immunology. 2007; 7:329-339.

46. Moore F, Santin I, Nogueira TC, Gurzov EN, Marselli L, Marchetti P and Eizirik DL. The transcription factor $\mathrm{C} /$ EBP delta has anti-apoptotic and anti-inflammatory roles in pancreatic beta cells. PloS one. 2012; 7:e31062.

47. Balamurugan $\mathrm{K}$ and Sterneck E. The many faces of $\mathrm{C} /$ EBPdelta and their relevance for inflammation and cancer. International journal of biological sciences. 2013; 9:917933.
48. Dawood S, Austin L and Cristofanilli M. Cancer stem cells: implications for cancer therapy. Oncology (Williston Park). 2014; 28:1101-1107, 1110.

49. Ebben JD, Treisman DM, Zorniak M, Kutty RG, Clark PA and Kuo JS. The cancer stem cell paradigm: a new understanding of tumor development and treatment. Expert opinion on therapeutic targets. 2010; 14:621-632.

50. Keysar SB and Jimeno A. More than markers: biological significance of cancer stem cell-defining molecules. Molecular cancer therapeutics. 2010; 9:2450-2457.

51. Pan Q, Li Q, Liu S, Ning N, Zhang X, Xu Y, Chang AE and Wicha MS. Concise Review: Targeting Cancer Stem Cells Using Immunologic Approaches. Stem Cells. 2015; 33:2085-2092.

52. Wang B, Wang Q, Wang Z, Jiang J, Yu SC, Ping YF, Yang J, Xu SL, Ye XZ, Xu C, Yang L, Qian C, Wang JM, Cui YH, Zhang X and Bian XW. Metastatic consequences of immune escape from NK cell cytotoxicity by human breast cancer stem cells. Cancer research. 2014; 74:5746-5757.

53. Tallerico R, Todaro M, Di Franco S, Maccalli C, Garofalo C, Sottile R, Palmieri C, Tirinato L, Pangigadde PN, La Rocca R, Mandelboim O, Stassi G, Di Fabrizio E, Parmiani G, Moretta A, Dieli F, et al. Human NK cells selective targeting of colon cancer-initiating cells: a role for natural cytotoxicity receptors and MHC class I molecules. J Immunol. 2013; 190:2381-2390.

54. Tucker JA, Jochems C, Boyerinas B, Fallon J, Greiner JW, Palena C, Rodell TC, Schlom J and Tsang KY. Identification and characterization of a cytotoxic T-lymphocyte agonist epitope of brachyury, a transcription factor involved in epithelial to mesenchymal transition and metastasis. Cancer immunology, immunotherapy. 2014; 63:1307-1317.

55. Hamilton DH, Fernando RI, Schlom J and Palena C. Aberrant expression of the embryonic transcription factor brachyury in human tumors detected with a novel rabbit monoclonal antibody. Oncotarget. 2015; 6:4853-4862. doi:10.18632/oncotarget.3086. 